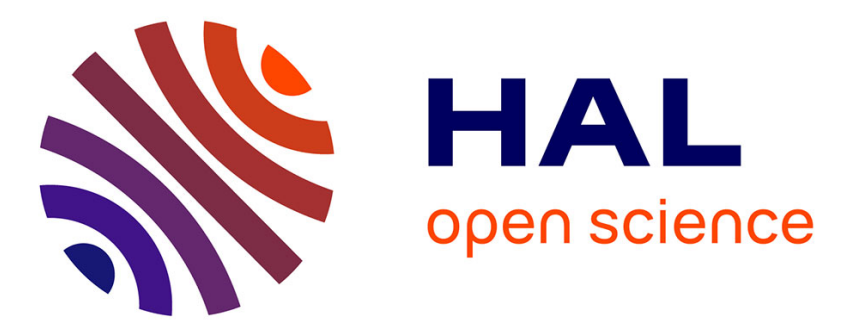

\title{
Platinum-Catalyzed Hydroamination of Ethylene: Study of the Catalyst Decomposition Mechanism
}

Aurélien Béthegnies, Jean-Claude Daran, Rinaldo Poli

\section{To cite this version:}

Aurélien Béthegnies, Jean-Claude Daran, Rinaldo Poli. Platinum-Catalyzed Hydroamination of Ethylene: Study of the Catalyst Decomposition Mechanism. Organometallics, 2013, 32 (2), pp.673-681. 10.1021/om301182x . hal-02907520

\section{HAL Id: hal-02907520 \\ https://hal.science/hal-02907520}

Submitted on 3 Mar 2021

HAL is a multi-disciplinary open access archive for the deposit and dissemination of scientific research documents, whether they are published or not. The documents may come from teaching and research institutions in France or abroad, or from public or private research centers.
L'archive ouverte pluridisciplinaire HAL, est destinée au dépôt et à la diffusion de documents scientifiques de niveau recherche, publiés ou non, émanant des établissements d'enseignement et de recherche français ou étrangers, des laboratoires publics ou privés. 


\title{
Platinum-catalyzed hydroamination of ethylene: study of the catalyst decomposition mechanism
}

\author{
Aurélien Béthegnies, ${ }^{a, b}$ Jean-Claude Daran ${ }^{a, b}$ and Rinaldo Poli*a,b,c \\ ${ }^{a}$ CNRS, LCC (Laboratoire de Chimie de Coordination), 205 route de Narbonne, \\ BP 44099, F-31077 Toulouse Cedex 4, France. \\ ${ }^{\mathrm{b}}$ Université de Toulouse, UPS, INPT, F-31077 Toulouse Cedex 4, France \\ ${ }^{\mathrm{c}}$ Institut Universitaire de France, 103, bd Saint-Michel, 75005 Paris, France
}

KEYWORDS: Platinum, Ethylene ligand, hydroamination, catalyst degradation, mechanistic study. 
TABLE OF CONTENT GRAPHIC.

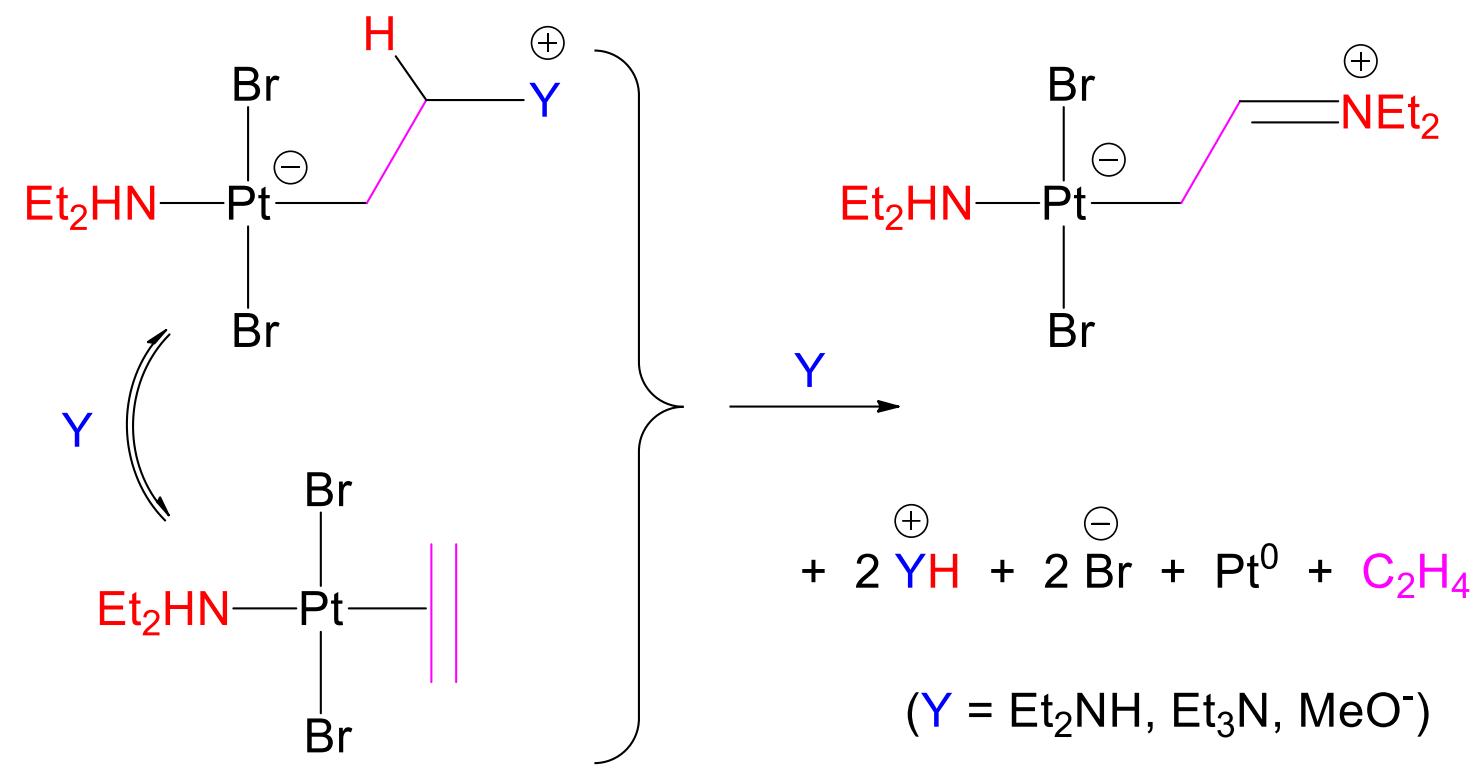


ABSTRACT (Word Style "BD_Abstract").

A study of the addition of nucleophilic reagents that are also strong Brønsted bases $\left(\mathrm{Et}_{3} \mathrm{~N}\right.$, pyridine, quinuclidine, $\left.\mathrm{MeO}^{-}\right)$to $n \mathrm{Bu}_{4} \mathrm{P}^{+}\left[\mathrm{PtBr}_{3}\left(\mathrm{C}_{2} \mathrm{H}_{4}\right)\right]^{-}(\mathbf{1})$ and trans- $\left[\mathrm{PtBr}_{2}\left(\mathrm{NHEt}_{2}\right)\left(\mathrm{C}_{2} \mathrm{H}_{4}\right)\right]$ (7) has provided key information on the deactivation of the hydroamination $\mathrm{PtBr}_{2} / \mathrm{Br}^{-}$catalyst, leading to metallic platinum. The addition of $\mathrm{NEt}_{3}$ to $\mathbf{1}$ in $\mathrm{CD}_{2} \mathrm{Cl}_{2}$ is reversible and temperature dependent; the quantitative formation of the zwitterionic complex trans-[ $\mathrm{Pt}^{(-)} \mathrm{Br}_{2}\left(\mathrm{NEt}_{3}\right)$ $\left.\left(\mathrm{CH}_{2} \mathrm{CH}_{2} \mathrm{~N}^{(+)} \mathrm{Et}_{3}\right)\right](9)$ is observed only at low temperature whereas slow deposition of metallic platinum occurs at room temperature. The addition of $\mathrm{NEt}_{3}$ to 7 in $\mathrm{CD}_{2} \mathrm{Cl}_{2}$ is also reversible and temperature dependent, yielding trans- $\left[\mathrm{Pt}^{(-)} \mathrm{Br}_{2}\left(\mathrm{NHEt}_{2}\right)\left(\mathrm{CH}_{2} \mathrm{CH}_{2} \mathrm{~N}^{(+)} \mathrm{Et}_{3}\right)\right]$ (10) quantitatively at low temperature. At room temperature, this reaction led to the deposition of metallic platinum and to the formation of a complex identified as trans-[ $\left.\mathrm{PtBr}_{2}\left(\mathrm{NHEt}_{2}\right)\left(\mathrm{CH}_{2} \mathrm{CHNEt}_{2}\right)\right]$ (11). The carbyl ligand in $\mathbf{1 1}$ is shown by an X-ray structural study to be in-between the $\pi$-bonded enamine and the $\sigma$-bonded iminiumalkyl configurations. The addition of $\mathrm{MeONa}$ to 7 results in the formation of the same products $\mathbf{1 1}$ and $\mathrm{Pt}^{0}$. On the basis of these results, a mechanism for the base-induced decomposition of $\mathrm{Pt}^{\mathrm{II}}\left(\mathrm{C}_{2} \mathrm{H}_{4}\right)$ complexes that involves Wacker-type $\beta$-H elimination followed by intermolecular hydride transfer, ligand rearrangements and final deprotonation is proposed. Addition of more nucleophilic N-based ligands (pyridine, quinuclidine) to 7 ultimately leads to $\mathrm{C}_{2} \mathrm{H}_{4}$ and $\mathrm{Et}_{2} \mathrm{NH}$ substitution rather than to metal reduction, even though evidence for a kinetically controlled nucleophilic addition to the coordinated ethylene is given by the quinuclidine system. From the reaction with pyridine, complex $c i s-\mathrm{PtBr}_{2}(\mathrm{py})_{2}$ was isolated and structurally characterized. 


\section{Introduction}

The intermolecular olefin hydroamination process opens access to higher amines by atom economical addition of an amine $\mathrm{N}-\mathrm{H}$ bond across the $\mathrm{C}=\mathrm{C}$ bond of the olefin and currently attracts considerable academic interest. ${ }^{1-3}$ This is a kinetically difficult reaction, especially for simple alkenes that lack activation by either electron-withdrawing groups such as acrylates, electronic delocalization such as styrene, or ring strain such as norbornene. Brunet has recently disclosed the remarkable activity of the simple platinum dihalides $\mathrm{PtX}_{2}(\mathrm{X}=\mathrm{Cl}, \mathrm{Br}$, I), when activated by $\left[n \mathrm{Bu}_{4} \mathrm{P}\right] \mathrm{X}$ (particularly for $\mathrm{X}=\mathrm{Br}$ ), for the addition of anilines to ethylene $\mathrm{e}^{4,5}$ and 1hexene. ${ }^{5,6}$ Turnover numbers up to 115 for the desired $N$-ethylaniline product from ethylene and aniline were reported for operation at 25 bars of ethylene pressure in $10 \mathrm{~h}$ at $150^{\circ} \mathrm{C}$ (i.e. a TOF of $11.5 \mathrm{~h}^{-1}$ on average), the selectivity being relatively high with only trace amounts of the double hydroamination product, $\mathrm{PhNEt}_{2}$, and ca. 10 turnovers for the formation of 2-methylquinoline (quinaldine) as a by-product. The process could also be extended to aqueous biphasic conditions, using $\mathrm{NaBr}$ as activator and $\mathrm{K}_{2} \mathrm{PtCl}_{4}$ as precatalyst, ${ }^{7}$ and tolerates the presence of air. Isolation and equilibrium studies of simple platinum complexes containing catalytically relevant species (ethylene, aniline, bromide) as ligands, such as $\left[\mathrm{PtBr}_{3}\left(\mathrm{C}_{2} \mathrm{H}_{4}\right)\right]^{-}(\mathbf{1})$, trans- $\left[\mathrm{PtBr}_{2}\left(\mathrm{C}_{2} \mathrm{H}_{4}\right)\left(\mathrm{PhNH}_{2}\right)\right]$ (2) and cis-[ $\left.\mathrm{PtBr}_{2}\left(\mathrm{PhNH}_{2}\right)_{2}\right](3),{ }^{8}$ backed up by DFT calculations, ${ }^{8-10}$ led to the conclusion that $\mathbf{1}$ is the catalyst resting state while a thorough computational investigation clarified the mechanistic pathway as summarized in Scheme 1. This involves olefin activation, followed by nucleophilic attach of the olefin by aniline, proton transfer from the ammonium function of the zwitterionic intermediate 4 to the metal center and final $\mathrm{C}-\mathrm{H}$ reductive elimination from the $\mathrm{Pt}^{\mathrm{IV}}$ hydrido derivative 5 via the $\sigma$-complex $6 .^{11}$ 
This catalytic system is haunted, however, by slow deactivation to metallic platinum, which is inactive for hydroamination although slightly active for amine transalkylation. ${ }^{12}$ This process has been traced to the effect of Brønsted basicity, because the presence of non coordinating bases stronger than aniline such as $\mathrm{Et}_{3} \mathrm{~N}$ and DBU totally deactivates the catalyst with the generation of massive amounts of $\mathrm{Pt}^{0}$. Although deactivation by Brønsted basicity is often considered indication of Brønsted acid catalysis (typically related to the hydroamination of more reactive olefins), ${ }^{13}$ this is not the case here because control experiments show the complete inactivity of strong Brønsted acids for the aniline addition to ethylene. ${ }^{12}$ The basicity causes the catalyst reduction to $\mathrm{Pt}^{0}$ in this case. Stability tests in the presence of only one of the two reagents (ethylene alone or aniline alone) did not result in the formation of any metallic $\mathrm{Pt},{ }^{14}$ indicating that the catalyst decomposition occurs only after the formation of the zwitterion 4 in the catalytic cycle.

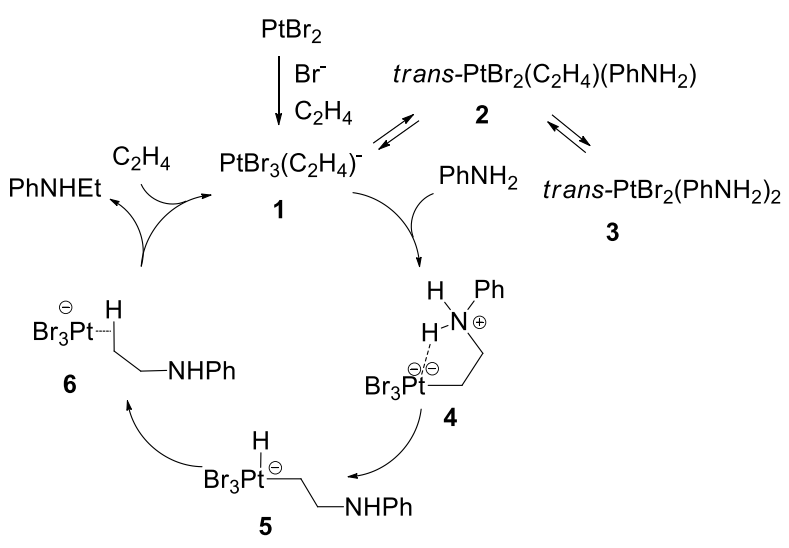

Scheme 1 . Mechanism of the aniline addition to ethylene catalyzed by $\mathrm{PtBr}_{2} / \mathrm{Br}^{-}$.

Since the intermediate 4 was not experimentally observable for the catalytic system in agreement with the DFT study, a model study was carried out with a more basic amine, Et ${ }_{2} \mathrm{NH}$, 
which is too basic to yield any hydroamination because it leads to rapid catalyst decomposition ${ }^{12}$, the desired zwitterion could indeed be observed after addition to 1, after an initial ligand exchange step yielding trans-[ $\left.\mathrm{PtBr}_{2}\left(\mathrm{Et}_{2} \mathrm{NH}\right)\left(\mathrm{C}_{2} \mathrm{H}_{4}\right)\right]$ (7). A second $\mathrm{Et}_{2} \mathrm{NH}$ molecule attacked the coordinated olefin in an equilibrium process with formation of trans-[ $\mathrm{Pt}^{(-)} \mathrm{Br}_{2}\left(\mathrm{Et}_{2} \mathrm{NH}\right)$ $\left.\left(\mathrm{CH}_{2} \mathrm{CH}_{2} \mathrm{~N}^{(+)} \mathrm{HEt}_{2}\right)\right]$ (8), which could be characterized by ${ }^{1} \mathrm{H}$ NMR and IR spectroscopies. The NMR study gave further evidence of a thermally accessible equilibrium deprotonation by the excess $\mathrm{Et}_{2} \mathrm{NH}$ to yield a trans-[ $\left.\mathrm{PtBr}_{2}\left(\mathrm{Et}_{2} \mathrm{NH}\right)\left(\mathrm{CH}_{2} \mathrm{CH}_{2} \mathrm{NEt}_{2}\right)\right]^{-}\left[\mathrm{Et}_{2} \mathrm{NH}_{2}\right]^{+}$ion pair intermediate. ${ }^{15}$ Subsequent monitoring of the solution at room temperature led to slow $\mathrm{Pt}^{0}$ precipitation.

The nucleophilic addition to olefins coordinated to $\mathrm{Pt}^{\mathrm{II}}$ has been intensively investigated. ${ }^{16-23} \mathrm{In}$

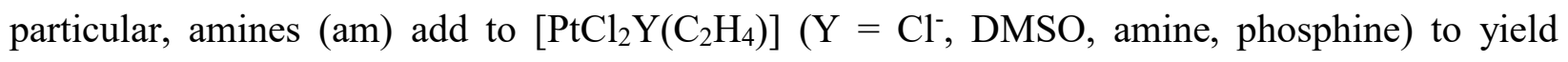
$\left[\mathrm{Pt}^{(-)} \mathrm{Cl}_{2} \mathrm{Y}\left(\mathrm{CH}_{2} \mathrm{CH}_{2} \mathrm{am}^{(+)}\right)\right]$which then may evolve in different ways depending on the nature of the amine and $\mathrm{Y} .{ }^{24-36}$ For complexes of type trans-[ $\left.\mathrm{PtCl}_{2}\left(\mathrm{C}_{2} \mathrm{H}_{4}\right)(\mathrm{am})\right]$, the observation of the zwitterionic product, which included an X-ray crystallographically characterized example, ${ }^{26}$ was limited to amines of high basicity, in agreement with our observations for the bromide analogues. Occasionally, slow decomposition of these products with deposition of metallic platinum was reported.

One specific contribution by Balacco and Natile (henceforth abbreviated as $\mathrm{BN})^{37}$ reported the ${ }^{1} \mathrm{H}$ NMR characterization of the product that results from the decomposition of trans$\left[\mathrm{Pt}^{(-)} \mathrm{Cl}_{2}\left(\mathrm{NHRR}^{\prime}\right)\left(\mathrm{CH}_{2} \mathrm{CH}_{2} \mathrm{~N}^{(+)} \mathrm{HRR}^{\prime}\right)\right]$, which was obtained from the addition of secondary amines NHRR' $\left(\mathrm{R}, \mathrm{R}^{\prime}=\right.$ cyclo- $\left.\left(\mathrm{CH}_{2}\right)_{5} ; \mathrm{Et}, \mathrm{Et} ; \mathrm{Me}, \mathrm{CHMePh}\right)$ to $\left[\mathrm{PtCl}_{3}\left(\mathrm{C}_{2} \mathrm{H}_{4}\right)\right]^{-}$. The reaction led to the formation, in addition to metallic platinum, of complexes trans-[ $\mathrm{PtCl}_{2}\left(\mathrm{NHRR}^{\prime}\right)$ $\left.\left(\mathrm{CH}_{2} \mathrm{CHNRR}\right)\right]$ according to the stoichiometry of equation 1. A mechanism for this transformation, involving deprotonation followed by loss of a hydride from the $\beta$ position of the 
aminoalkyl ligand, was proposed as illustrated in Scheme 2. However, the reason for the spontaneous hydride loss and the detailed mechanism of this transformation were not clarified.

\section{2 trans $-\left[\mathrm{PtCl}_{2}\left(\mathrm{NHRR}^{\prime}\right)\left(\mathrm{CH}_{2} \mathrm{CH}_{2} \mathrm{NHRR}^{\prime}\right)\right] \rightarrow$ trans-[$\left[\mathrm{PtCl}_{2}\left(\mathrm{NHRR}^{\prime}\right)\left(\mathrm{CH}_{2} \mathrm{CHNRR}^{\prime}\right)\right]+$

$$
\mathrm{Pt}+\mathrm{C}_{2} \mathrm{H}_{4}+2 \mathrm{NH}_{2} \mathrm{RR}^{\prime+} \mathrm{Cl}^{-}
$$

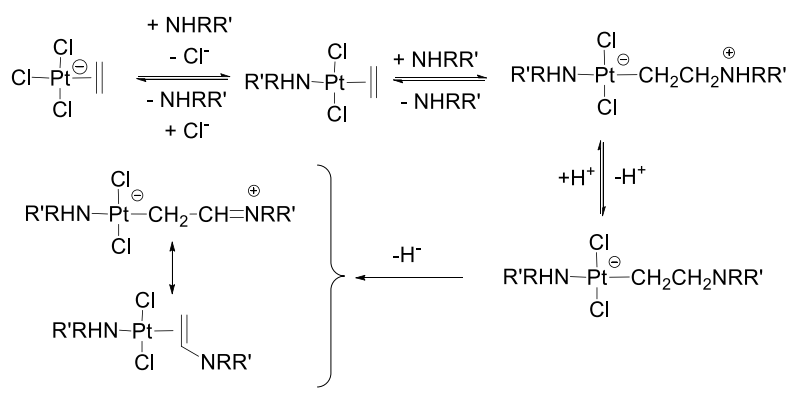

Scheme 2. Proposed mechanism for the decomposition of trans-[ $\mathrm{PtCl}_{2}\left(\mathrm{NHRR}^{\prime}\right)$ $\left.\left(\mathrm{CH}_{2} \mathrm{CH}_{2} \mathrm{NHRR}^{\prime}\right)\right] .^{37}$

Another phenomenon is of relevance to our observed catalyst deactivation. Whereas alkoxyalkyl complexes with the $\left[\mathrm{PtCl}(\mathrm{N}-\mathrm{N})\left(\mathrm{CH}_{2} \mathrm{CH}_{2} \mathrm{OR}\right)\right](\mathrm{R}=$ alkyl) stoichiometry, obtained by nucleophilic addition of $\mathrm{RO}^{-}$to coordinated ethylene, are stable, ${ }^{22,38-40}$ those containing 2,9$\mathrm{Me}_{2}$ phen were recently reported by Fanizzi et al. to spontaneously decompose to give $\mathrm{Pt}^{0}$ and the corresponding vinyl ethers, $\mathrm{CH}_{2}=\mathrm{CHOR}(\mathrm{R}=\mathrm{Me}, \mathrm{Bu})$, via a proposed Wacker-type mechanism involving $\beta$-H elimination, see Scheme 3, which was supported by mass spectrometric and NMR evidence of the $\left[\mathrm{PtCl}(\mathrm{H})\left(2,9-\mathrm{Me}_{2}\right.\right.$ phen $\left.)\right]$ intermediate ${ }^{41}$ The reason advanced by the authors for this reduced stability is the steric destabilization of the square planar configuration by the two phenantroline methyl substituents, promoting chelate ring opening and triggering the $\beta-\mathrm{H}$ elimination process. The observed $\mathrm{Pt}^{0}$ product obviously results by action of a base on the $\mathrm{Pt}^{\mathrm{II}}$ 
hydride intermediate. This observation interrogated us about the possibility that $\beta$ - $\mathrm{H}$ elimination may also cause the decomposition of our catalytic system, as well as that of the above mentioned aminoalkyl complexes (Scheme 2).

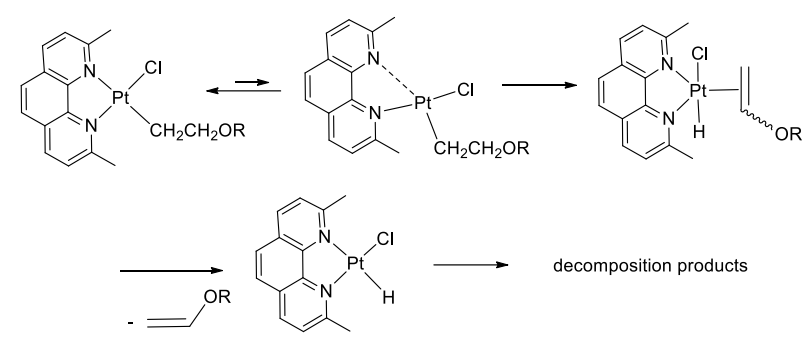

Scheme 3. Proposed mechanism for the decomposition of $\left[\mathrm{PtCl}\left(2,9-\mathrm{Me}_{2} \mathrm{phen}\right)\left(\mathrm{CH}_{2} \mathrm{CH}_{2} \mathrm{OR}\right)\right] .{ }^{22}$

In this contribution, we present our studies on the decomposition of $\left[\mathrm{PtBr}_{3}\left(\mathrm{C}_{2} \mathrm{H}_{4}\right)\right]^{-}$in the presence of amines ( $\mathrm{NEt}_{3}$, py, quinuclidine) and the methoxide anion $\left(\mathrm{MeO}^{-}\right)$, providing additional insight on the decomposition pathway of the hydroamination catalyst.

\section{Experimental Section}

General. All operations were carried out in Schlenk glassware under an argon atmosphere. $\mathrm{CH}_{2} \mathrm{Cl}_{2}$ was of $\mathrm{HPLC}$ grade and was distilled on $\mathrm{CaH}_{2}$ under argon. $\mathrm{CD}_{2} \mathrm{Cl}_{2}$ for the NMR studies was obtained from Euriso-top as flame-sealed $0.6 \mathrm{~mL}$ ampoules. $\mathrm{NEt}_{3}(99+\%$, Acros Organics), $\mathrm{HNEt}_{2}$ (Fluka) and $\mathrm{C}_{5} \mathrm{H}_{5} \mathrm{~N}$ (Jansen) were distilled and kept under argon in the dark. MeONa (Fluka) was dehydrated and stored in a Schlenk tube under argon. Quinuclidine was purified by recrystallization according to the literature process. ${ }^{42} \mathrm{PtBr}_{2}$ (99.9 \%, Aldrich), $n \mathrm{Bu} 4 \mathrm{PBr}(98 \%$, Acros Organics), and $\mathrm{Ph}_{4} \mathrm{PBr}$ (98+\%, Avocado) were used as received. Complexes $\mathrm{Ph}_{4} \mathrm{P}\left[\mathrm{PtBr}_{3}\left(\mathrm{C}_{2} \mathrm{H}_{4}\right)\right], \quad n \mathrm{Bu}_{4} \mathrm{P}\left[\mathrm{PtBr}_{3}\left(\mathrm{C}_{2} \mathrm{H}_{4}\right)\right]$ and trans-[ $\left.\mathrm{PtBr}_{2}\left(\mathrm{C}_{2} \mathrm{H}_{4}\right)\left(\mathrm{HNEt}_{2}\right)\right]$ were synthesized 
according to the literature process. ${ }^{8,14}$ Ethylene (purity $\geq 99.5 \%$ ) was purchased from Air Liquide.

Instrumentation. The ${ }^{1} \mathrm{H}$ NMR investigations were carried out at $298 \mathrm{~K}$ on Bruker DPX300 or AV400 instruments operating respectively at 300.13 and $400.10 \mathrm{MHz}$. The low temperature NMR studies were carried out on a Bruker AV500 at $218 \mathrm{~K}$, operating at $500.33 \mathrm{MHz}$. The spectra were calibrated with the residual solvent resonance and reported with positive chemical shifts in ppm relative to TMS.

Reaction of $\left[\mathbf{P h}_{4} \mathbf{P}\right]\left[\mathbf{P t B r}_{3}\left(\mathbf{C}_{2} \mathbf{H}_{4}\right)\right]$ with NEt $_{3}$. Compound $\mathrm{Ph}_{4} \mathrm{P}\left[\mathrm{PtBr}_{3}\left(\mathrm{C}_{2} \mathrm{H}_{4}\right)\right](10.2 \mathrm{mg}$, $0.0127 \mathrm{mmol}$ ) was introduced in a 5-mm NMR tube. After a series of vacuum/argon cycles, the solid was dissolved in $0.6 \mathrm{~mL}$ of $\mathrm{CD}_{2} \mathrm{Cl}_{2}$. $\mathrm{NEt}_{3}(17 \mu \mathrm{L}, 12.34 \mathrm{mg}, 0.122 \mathrm{mmol})$ was then slowly added by microsyringe. The solution was then homogenized and used for the NMR investigation.

Reaction of trans-[ $\left.\mathrm{PtBr}_{2}\left(\mathrm{NHEt}_{2}\right)\left(\mathrm{C}_{2} \mathrm{H}_{4}\right)\right]$ with $\mathrm{NEt}_{3}$. (a) NMR monitoring. In two parallel experiments, samples of compound trans-[ $\left.\mathrm{PtBr}_{2}\left(\mathrm{NHEt}_{2}\right)\left(\mathrm{C}_{2} \mathrm{H}_{4}\right)\right]$ (ca.10 mg, ca. $0.022 \mathrm{mmol}$ ) were introduced in 5-mm NMR tubes. After a series of vacuum/argon cycles, each sample was dissolved in $0.6 \mathrm{~mL}$ of $\mathrm{CD}_{2} \mathrm{Cl}_{2}$ and the tube was cooled to $-80{ }^{\circ} \mathrm{C}$ in an acetone/liquid nitrogen bath. To each tube was then slowly added $\mathrm{NEt}_{3}(6.2 \mu \mathrm{L}, 4.5 \mathrm{mg}, 0.044 \mathrm{mmol}$ for one; $15.4 \mu \mathrm{L}$, $11.2 \mathrm{mg}, 0.110 \mathrm{mmol}$ for the other one) by microsyringe through a rubber septum. The resulting mixture was homogenized and analyzed by NMR.

(b) Synthesis of complex $\left[\left(\mathbf{E t}_{2} \mathrm{NH}\right) \mathrm{PtBr}_{2}\left(\mathrm{CH}_{2}=\mathrm{CHNEt}_{2}\right)\right]$. Complex trans$\left[\mathrm{PtBr}_{2}\left(\mathrm{NHEt}_{2}\right)\left(\mathrm{C}_{2} \mathrm{H}_{4}\right)\right](20.5 \mathrm{mg}, 0.029 \mathrm{mmol})$ was placed in a Schlenk tube and dissolved in dichloromethane $(2 \mathrm{~mL})$. Triethylamine $(5 \mu \mathrm{L}, 0.036 \mathrm{mmol}, 0.036 \mathrm{mmol})$ was then added by microsyringe. The mixture was then refluxed for $48 \mathrm{~h}$, after which the solvent was removed by evaporation under reduced pressure. The reaction residue was purified according to procedure 
described by $\mathrm{BN}^{37}$ : it was chromatographed through a silica gel column using dichloromethane as eluent. The first colored fraction was collected and evaporated to dryness. It was characterized by ${ }^{1} \mathrm{H}$ NMR spectroscopy, mass spectrometry and X-ray diffraction. ${ }^{1} \mathrm{H}$ NMR $\left(\mathrm{CDCl}_{3}\right): \delta 7.71(\mathrm{t}$, $\left.\mathrm{J}=9.2 \mathrm{~Hz}, 1 \mathrm{H},-\mathrm{CH}_{2} \mathrm{CHN}\right), 3.57\left(\mathrm{br}, 2 \mathrm{H}, \mathrm{CH}_{-} \mathrm{NCH}_{2} \mathrm{CH}_{3}\right), 3.46\left(\mathrm{~d}, \mathrm{~J}=9.2 \mathrm{~Hz}, 2 \mathrm{H},-\mathrm{CH}_{2} \mathrm{CHN}\right)$, $3.21\left(\mathrm{~m}, 2 \mathrm{H}, \mathrm{CH}_{3} \mathrm{CH}_{2} \mathrm{~N}-\mathrm{Pt}\right), 2.73\left(\mathrm{~m}, 2 \mathrm{H}, \mathrm{CH}_{3} \mathrm{CH}_{2} \mathrm{~N}-\mathrm{Pt}\right), 1.50\left(\mathrm{t}, \mathrm{J}=7.0 \mathrm{~Hz}, 6 \mathrm{H}, \mathrm{CH}_{3} \mathrm{CH}_{2} \mathrm{~N}-\mathrm{Pt}\right)$, $1.30\left(\mathrm{~m}, 2 \mathrm{H}, \mathrm{CH}-\mathrm{NCH}_{2} \mathrm{CH}_{3}\right), 1.25\left(\mathrm{t}, \mathrm{J}=7.2 \mathrm{~Hz}, 3 \mathrm{H}, \mathrm{CH}-\mathrm{NCH}_{2} \mathrm{CH}_{3}\right), 0.90(\mathrm{t}, \mathrm{J}=7.2 \mathrm{~Hz}, 3 \mathrm{H}$, CH-NCH $\left.\mathrm{CH}_{3}\right)$. MS (DCI, $\left.\mathrm{NH}_{3}\right)$ : $529.1\left(\mathrm{M}^{+}+\mathrm{H}\right)$. A single crystal for the X-ray analysis was grown by slow evaporation of the $\mathrm{CDCl}_{3}$ solvent from the NMR tube.

Reaction of $\left[n \mathbf{B u}_{4} \mathrm{P}\right]\left[\mathrm{PtBr}_{3}\left(\mathrm{C}_{2} \mathrm{H}_{4}\right)\right]$ with pyridine. Complex $n \mathrm{Bu} 4 \mathrm{P}\left[\mathrm{PtBr}_{3}\left(\mathrm{C}_{2} \mathrm{H}_{4}\right)\right](24.6 \mathrm{mg}$, ca. $0.034 \mathrm{mmol}$ ) was introduced in a 5-mm NMR tube. After a series of vacuum/argon cycles, the solid was dissolved in $0.6 \mathrm{~mL}$ of $\mathrm{CD}_{2} \mathrm{Cl}_{2}$. To the solution was added pyridine $(9.2 \mu \mathrm{L}, 9.0$ $\mathrm{mg}, 0.114 \mathrm{mmol}$ ) by microsyringe through a rubber septum. No evidence for an immediate reaction was obtained from the ${ }^{1} \mathrm{H}$ NMR spectrum. Standing at room temperature overnight led to the deposition of single crystals, which were used for the X-ray structural analysis.

\section{Reaction of trans-[ $\left.\mathrm{PtBr}_{2}\left(\mathrm{NHEt}_{2}\right)\left(\mathrm{C}_{2} \mathrm{H}_{4}\right)\right]$ with quinuclidine. Complex trans-} $\left[\mathrm{PtBr}_{2}\left(\mathrm{NHEt}_{2}\right)\left(\mathrm{C}_{2} \mathrm{H}_{4}\right)\right](10.2 \mathrm{mg}, 0.0236 \mathrm{mmol})$ and quinuclidine $(4.8 \mathrm{mg}, 0.0432 \mathrm{mmol})$ were placed separately into 5-mm NMR tubes, placed under argon and dissolved into $\mathrm{CD}_{2} \mathrm{Cl}_{2}$ (ca. 0.3 $\mathrm{mL})$ at $-80^{\circ} \mathrm{C}$. The platinum complex solution was then transferred into the quinuclidine solution NMR tube. The resulting solution was homogenized before being analyzed by NMR spectroscopy at regular intervals.

Reaction of trans-[PtBr $\left.2\left(\mathrm{NHEt}_{2}\right)\left(\mathrm{C}_{2} \mathrm{H}_{4}\right)\right]$ with MeONa. Complex trans$\left[\mathrm{PtBr}_{2}\left(\mathrm{NHEt}_{2}\right)\left(\mathrm{C}_{2} \mathrm{H}_{4}\right)\right](10.2 \mathrm{mg}, 0.0236 \mathrm{mmol})$ and $\mathrm{MeONa}(2.6 \mathrm{mg}, 0.048 \mathrm{mmol})$ were placed into a 5-mm NMR tube. After a series of vacuum/argon cycles, $0.6 \mathrm{~mL}$ of $\mathrm{CD}_{2} \mathrm{Cl}_{2}$ was added at - 
$80^{\circ} \mathrm{C}$, dissolving the platinum complex. Since no reaction was observed over 3 hours at $-80^{\circ} \mathrm{C}$, the tube was warmed to room temperature and monitored.

X-ray crystallography. A single crystal of each compound was mounted under inert perfluoropolyether at the tip of a cryoloop and cooled in the cryostream of either an Agilent Technologies Xcalibur CCD diffractometer for $\left[\mathrm{PtBr}_{2}\left(\mathrm{NC}_{5} \mathrm{H}_{5}\right)_{2}\right]$ or a Bruker Apex2 CCD diffractometer for 11. Data were collected using the monochromatic MoK $\alpha$ radiation $(\lambda=$ 0.71073). The structures were solved by direct methods (SIR97) ${ }^{43}$ and refined by least-squares procedures on $F^{2}$ using SHELXL-97. ${ }^{44}$ In the compound $\mathrm{PtBr}_{2}\left(\mathrm{NC}_{5} \mathrm{H}_{5}\right)_{2}$ all $\mathrm{H}$ atoms attached to carbon were introduced in idealised positions and treated as riding on their parent atoms in the calculations. In compound 11, the $\mathrm{H}$ atoms attached to the Pt-bonded carbon atom could not be located and were not calculated. The other atoms were introduced in idealised positions and treated as riding on their parent atoms in the calculations. The drawing of the molecules was realised with the help of ORTEP $3{ }^{45,46}$ Crystal data and refinement parameters are shown in Table S1. Crystallographic data (excluding structure factors) have been deposited with the Cambridge Crystallographic Data Centre as supplementary publication no. CCDC 914166 and 914167. Copies of the data can be obtained free of charge on application to the Director, CCDC, 12 Union Road, Cambridge CB2 1EZ, UK (fax: (+44) 1223-336-033; e-mail: deposit@.ccdc.cam.ac.uk).

\section{Results and Discussion}

\section{(a) Addition of trielthylamine to $\left[\mathrm{PtBr}_{3}\left(\mathrm{C}_{2} \mathrm{H}_{4}\right)\right]^{-}$}


In order to probe whether decomposition of the zwitterion, e.g. 4 in Scheme 1, requires deprotonation to yield an aminoalkyl ligand as proposed by BN (Scheme 2), we wished to investigate the reactivity of complex 1 toward non deprotonatable bases, starting with $\mathrm{Et}_{3} \mathrm{~N}$. Charging the solution of $\mathbf{1}$ with up to a 10 -fold excess of $\mathrm{Et}_{3} \mathrm{~N}$ did not reveal any change in the room temperature ${ }^{1} \mathrm{H}$ NMR spectrum of the starting compound and no new resonances appeared except for those of free $\mathrm{NEt}_{3}$. This is consistent with literature reports on the analogous chloride system, according to which the formation of equilibrium amounts of the zwitterionic product was only possible for highly basic secondary amines such as $\mathrm{Et}_{2} \mathrm{NH}$ and piperidine. Indeed, we found in our previous study ${ }^{15}$ that treatment of compound 7 (obtained from 1 and one equivalent of $\mathrm{NHEt}_{2}$ ) with two additional equivalents of $\mathrm{NHEt}_{2}$ is sufficient to promote an essentially quantitative amine addition to the coordinated ethylene. However, cooling the $\mathbf{1} / \mathrm{NEt}_{3}$ (10 equiv) solution to $-80^{\circ} \mathrm{C}$ in the NMR probe revealed the extensive formation of a new product that can be assigned to trans-[ $\left[\mathrm{Pt}^{(-)} \mathrm{Br}_{2}\left(\mathrm{NEt}_{3}\right)\left(\mathrm{CH}_{2} \mathrm{CH}_{2} \mathrm{~N}^{(+)} \mathrm{Et}_{3}\right)\right]$, 9. The ${ }^{1} \mathrm{H}$ NMR spectrum is shown in Figure 1. Note that, in order to keep the aliphatic proton resonances clear from the interference of cation resonances, the $\mathrm{Ph}_{4} \mathrm{P}^{+}$salt of complex 1 was used in this experiment.

The identity of the compound is demonstrated by the two characteristic triplets in a 1:1 ratio of the mutually coupled eth-di-yl protons of the $-\mathrm{CH}_{2} \mathrm{CH}_{2} \mathrm{~N}^{(+)} \mathrm{Et}_{3}$ ligand at $\delta 3.18$ and $2.04\left({ }^{3} \mathrm{~J}_{\mathrm{HH}}=\right.$ $8.2 \mathrm{~Hz})$. For comparison, those observed for trans- $\left[\mathrm{Pt}^{(-)} \mathrm{Br}_{2}\left(\mathrm{NHEt}_{2}\right)\left(\mathrm{CH}_{2} \mathrm{CH}_{2} \mathrm{~N}^{(+)} \mathrm{HEt}_{2}\right)\right]$ appear at $\delta 2.86$ and 2.09 with ${ }^{3} \mathrm{~J}_{\mathrm{HH}}=7.0 \mathrm{~Hz} \cdot{ }^{15}$ The resonances of the two compounds are compared in Table 1. The ammonium $-\mathrm{N}^{(+)} \mathrm{Et}_{3}$ group exhibits the sharper methylene and methyl proton resonances with the greater downfield shift relative to those of the excess free $\mathrm{NEt}_{3}$, whereas those of the coordinated $\mathrm{NEt}_{3}$ ligand are less downfield shifted and broader, the latter feature probably being caused by an incompletely frozen exchange with the free ligand. These trends 
parallel those previously reported for the $\mathrm{NHEt}_{2}$ analogue (see Table 1). Although there is no specific feature in the ${ }^{1} \mathrm{H}$ NMR spectrum to distinguish the trans and cis stereochemistries, a trans configuration can be assigned to the product on the basis of the reasonable hypothesis that the stronger trans effect of the ethylene ligand directs the initial ligand exchange process. As suggested by our previous DFT study, ${ }^{11}$ replacement of the $\mathrm{Br}^{-}$ligand trans to ethylene with an amine is expected to favor the ethylene nucleophilic attack both kinetically and thermodynamically.

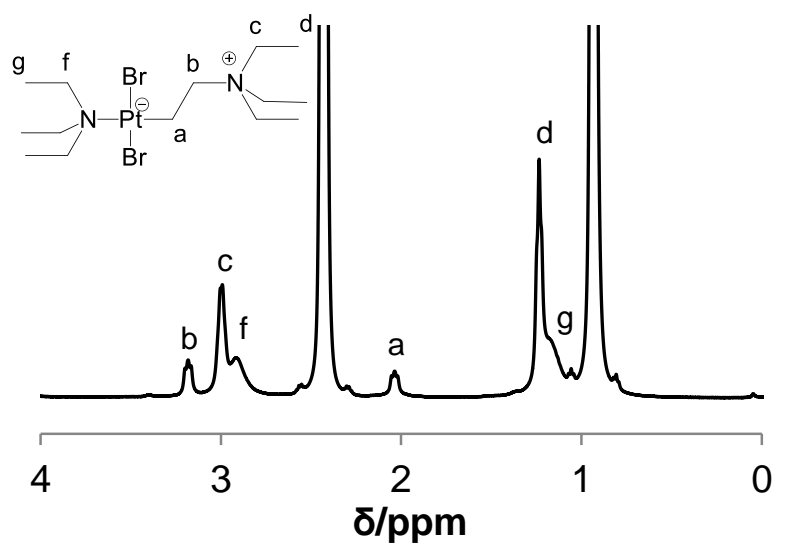

Figure 1. ${ }^{1} \mathrm{H}$ NMR spectrum in $\mathrm{CD}_{2} \mathrm{Cl}_{2}$ of a solution of $\left[\mathrm{Ph}_{4} \mathrm{P}\right]\left[\mathrm{PtBr}_{3}\left(\mathrm{C}_{2} \mathrm{H}_{4}\right)\right]$ and $\mathrm{NEt}_{3}$ (10 equiv) at $-80{ }^{\circ} \mathrm{C}$. The off-scale resonances belong to the methylene and methyl protons of the excess free $\mathrm{NEt}_{3}$.

Table 1. ${ }^{1} \mathrm{H}$ NMR resonances observed for various trans- $\left[\mathrm{Pt}^{(-)} \mathrm{Br}_{2}\left(\mathrm{NEt}_{2} \mathrm{R}^{\prime}\right)\left(\mathrm{CH}_{2} \mathrm{CH}_{2} \mathrm{~N}^{(+)} \mathrm{Et}_{2} \mathrm{R}\right)\right]$ compounds $\left(\mathrm{R}, \mathrm{R}^{\prime}=\mathrm{H}, \mathrm{Et}\right)$.

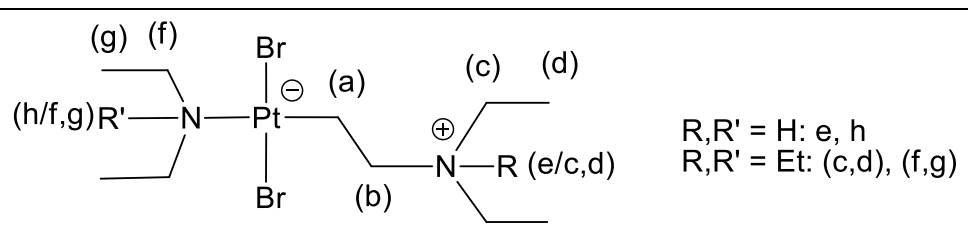




\begin{tabular}{|c|c|c|c|c|c|c|c|c|}
\hline $\mathrm{R}, \mathrm{R}^{\prime}$ & (a) & (b) & (c) & (d) & (e) & (f) & (g) & (h) \\
\hline $\mathrm{H}, \mathrm{H}^{\mathrm{a}}(\mathbf{8})$ & 2.09 & 2.86 & $\begin{array}{l}3.37 \\
3.21\end{array}$ & 1.42 & n.o. ${ }^{b}$ & $\begin{array}{l}\text { ca. } 3.08 \\
\text { ca. } 2.79\end{array}$ & 1.40 & 7.9 \\
\hline $\mathrm{Et}, \mathrm{Et}^{\mathrm{c}}(\mathbf{9})$ & 2.04 & 3.18 & 2.99 & 1.24 & - & 2.92 & ca. 1.18 & - \\
\hline $\mathrm{Et}, \mathrm{H}^{\mathrm{c}}(\mathbf{1 0})$ & 1.71 & 3.19 & 2.99 & 1.21 & - & $\begin{array}{l}2.92 \\
2.66\end{array}$ & 1.38 & 4.23 \\
\hline
\end{tabular}

${ }^{\mathrm{a}} \mathrm{In} \mathrm{CD}_{2} \mathrm{Cl}_{2}$ at room temperature (from ref. 15 ). ${ }^{\mathrm{b}}$ Not observed. ${ }^{\mathrm{c}}$ In $\mathrm{CD}_{2} \mathrm{Cl}_{2}$ at $-80{ }^{\circ} \mathrm{C}$.

Thus, contrary to previous reports, nucleophilic addition of $\mathrm{Et}_{3} \mathrm{~N}$ to a $\mathrm{Pt}^{\mathrm{II}}$-coordinated olefin may indeed be observed, at least for complex 1, although only at low temperatures. Warming the solution back to room temperature and subsequent ${ }^{1} \mathrm{H}$ NMR measurement indicated total reversal of the reaction to regenerate complex 1 quantitatively, with no trace of the zwitterionic product 9 left in solution. This can be rationalized by the fact that the addition reaction (equation 2) is severely exoentropic and hence highly temperature dependent. Being obviously exothermic, the process becomes favored at low temperatures where the impact of the $-\mathrm{T} \Delta \mathrm{S}$ term is reduced.

$$
\left[\mathrm{PtBr}_{3}\left(\mathrm{C}_{2} \mathrm{H}_{4}\right)\right]^{-}+2 \mathrm{NEt}_{3} \rightarrow \text { trans- }\left[\mathrm{Pt}^{(-)} \mathrm{Br}_{2}\left(\mathrm{NEt}_{3}\right)\left(\mathrm{CH}_{2} \mathrm{CH}_{2} \mathrm{~N}^{(+)} \mathrm{Et}_{3}\right)\right]+\mathrm{Br}^{-}
$$

1

The solution of $\mathbf{1}$ and excess $\mathrm{NEt}_{3}$ used for this NMR experiment was not indefinitely stable, giving rise to the slow precipitation of metallic platinum upon standing for a long time at room temperature. This observation is first evidence that the zwitterion decomposition does not require deprotonation of the ammonium function. On the basis of the recent report on the decomposition of alkoxylated olefin complexes (see Scheme 3 in the Introduction) ${ }^{41}$ and the well known 
mechanism of the Wacker process, it is possible to envisage occurrence of a $\beta-\mathrm{H}$ elimination to afford a $\mathrm{Pt}^{\mathrm{II}}$ hydride intermediate, which would be deprotonated by the excess base, ultimately leading to the formation of a vinylammonium cation, see Scheme 4.

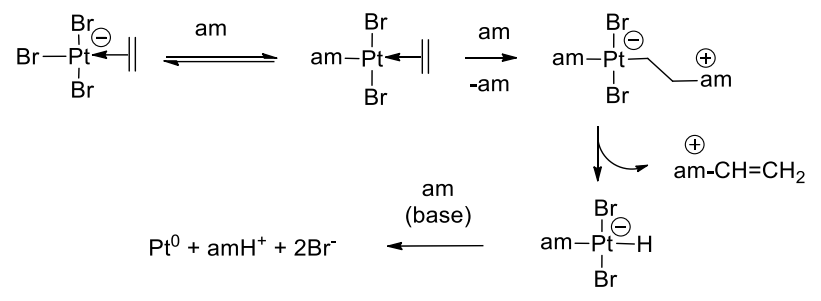

Scheme 4. Hypothesis for the decomposition of $\left[\mathrm{PtBr}_{3}\left(\mathrm{C}_{2} \mathrm{H}_{4}\right)\right]^{-}$in the presence of $\mathrm{NEt}_{3}$.

Vinylammonium cations are scarcely described in the literature, but a few examples are indeed known, for instance $\left[\mathrm{CH}_{2}=\mathrm{CHNMe}_{2} \mathrm{R}\right]^{+}(\mathrm{R}=\mathrm{Me}, \mathrm{Et}),{ }^{47}$ with the vinyl protons being observed by ${ }^{1} \mathrm{H}$ NMR in $\mathrm{D}_{2} \mathrm{O}$ in the 5.5-7.0 region. Monitoring the decomposition of the $\mathrm{CD}_{2} \mathrm{Cl}_{2}$ solution of $1+\mathrm{NEt}_{3}$ by ${ }^{1} \mathrm{H}$ NMR over 7 days, however, did not reveal the generation of any resonance in this region.

\section{(b) Addition of trielthylamine to trans-[ $\left.\mathrm{PtBr}_{2}\left(\mathrm{NHEt}_{2}\right)\left(\mathrm{C}_{2} \mathrm{H}_{4}\right)\right]$}

From our DFT studies of the catalytic cycle of the $\mathrm{PtBr}_{2} / \mathrm{Br}^{-}$catalyzed aniline addition to ethylene we have learnt that nucleophilic addition to the coordinated ethylene is both kinetically promoted and thermodynamically more favored when the trans $\mathrm{Br}^{-}$ligand is replaced by aniline. ${ }^{11}$ Therefore, we envisaged promoting the nucleophilic addition of $\mathrm{NEt}_{3}$ by using 7 as substrate.

In the presence of two equivalents of $\mathrm{NEt}_{3}$ in $\mathrm{CD}_{2} \mathrm{Cl}_{2}$, no changes in the ${ }^{1} \mathrm{H}$ NMR spectrum of 7 were observed and no new resonance appeared with the exception of those of the added $\mathrm{Et}_{3} \mathrm{~N}$. 
This behavior parallel that reported above for the addition of $\mathrm{NEt}_{3}$ to 1, but differs from that observed for the addition of $\mathrm{Et}_{2} \mathrm{NH}$ to 7 where formation of the zwitterionic product was nearly quantitative at room temperature under the same conditions. However, like for the above described $\mathrm{Et}_{3} \mathrm{~N}$ addition to 1, extensive formation of the expected zwitterionic product, trans$\left[\mathrm{Pt}^{(-)} \mathrm{Br}_{2}\left(\mathrm{NHEt}_{2}\right)\left(\mathrm{CH}_{2} \mathrm{CH}_{2} \mathrm{~N}^{(+)} \mathrm{Et}_{3}\right)\right]$ (10), was observed at low temperature (see Figure 2). Once again, the high negative reaction entropy accounts for the observed behavior. Upon letting the solution warm up to room temperature, the initial complex 7 forms again quantitatively, confirming the reversibility of the nucleophilic addition process.

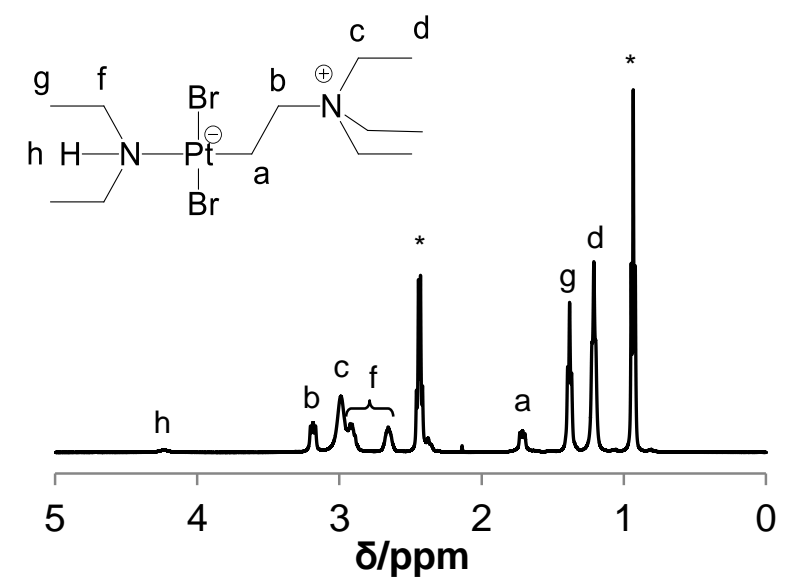

Figure 2. ${ }^{1} \mathrm{H}$ NMR spectrum in $\mathrm{CD}_{2} \mathrm{Cl}_{2}$ of a solution of trans- $\left[\mathrm{PtBr}_{2}\left(\mathrm{Et}_{2} \mathrm{NH}\right)\left(\mathrm{C}_{2} \mathrm{H}_{4}\right)\right]$ and $\mathrm{NEt}_{3}(2$ equiv) at $-80{ }^{\circ} \mathrm{C}$. The starred resonances belong to the methylene and methyl protons of the excess free $\mathrm{NEt}_{3}$.

The Pt- $\mathrm{CH}_{2} \mathrm{CH}_{2}-\mathrm{N}$ moiety is characterized in this case by mutually coupled $\left({ }^{3} \mathrm{~J}_{\mathrm{HH}}=8.8 \mathrm{~Hz}\right)$ triplet resonances at $\delta 3.19$ and 1.71 . In spite of the absence of observable platinum couplings, probably because of the strong chemical shift anisotropy relaxation mechanism and the high field of the used instrument, this feature is a clear signature for the zwitterion formation ( $c f$. the 
resonances of this compound with those of the similar ones in Table 1). The coordinated diethylamine ligand is characterized by two signals for the diastereotopic methylene protons at $\delta$ 2.66 and 2.92 and one for the Me protons at $\delta 1.38$, upfield shifted from those in the precursor compound $7,^{15}$ whereas the triethylammonium group shows the methylene and methyl resonances downfield shifted from the free amine, at $\delta 2.99$ and 1.21 , respectively. A ${ }^{1} \mathrm{H}$ COSY NMR experiment confirmed the coupling pattern in the compound.

When the solution containing compound 7 and $\mathrm{NEt}_{3}$ (2 equivalents) was left standing at room temperature for an extended period, a black precipitate started to deposit after ca. $24 \mathrm{~h}$. Monitoring this transformation by ${ }^{1} \mathrm{H}$ NMR showed no residual starting complex after 1 week. Hence, even though this zwitterionic product has once again a non deprotonable ammonium group, its decomposition to metallic platinum can nevertheless take place. The evolution of the ${ }^{1} \mathrm{H}$ NMR spectrum is shown in the supporting information (Figure S1). The notable feature of the final spectrum is the absence of any resonance attributable to a vinylammonium product, as could be expected on the basis of the decomposition pathway shown in Scheme 4. On the other hand, the spectrum clearly shows two mutually coupled resonances (confirmed by a ${ }^{1} \mathrm{H}$ COSY NMR spectrum), a triplet at $\delta 7.70$ and a doublet at $\delta 3.37$ in a 1:2 ratio with ${ }^{3} \mathrm{~J}_{\mathrm{HH}}=9 \mathrm{~Hz}$. Other visible resonances are attributable to free ethylene $(\delta 5.40)$ and to protonated triethylamine (single set of resonances downfield shifted from those of free triethylamine, as can be expected from a rapid degenerate exchange between $\mathrm{Et}_{3} \mathrm{~N}$ and $\mathrm{Et}_{3} \mathrm{NH}^{+}$). These signals have the same pattern and are observed at very similar positions as those of the enamine complexes trans$\left[\mathrm{PtCl}_{2}\left(\mathrm{NHRR}^{\prime}\right)\left(\mathrm{CH}_{2} \mathrm{CHNRR}\right)\right]$ reported by BN as the decomposition products of $\left[\mathrm{PtCl}_{3}\left(\mathrm{C}_{2} \mathrm{H}_{4}\right)\right]^{-}$ +2 NHRR' as mentioned in the Introduction. ${ }^{37}$ Obviously, the zwitterionic intermediate $\mathbf{1 0}$ could not lead to this type of product by the proposed pathway (Scheme 2) because the ammonium 
function cannot be deprotonated. Our next experiments were aimed at probing the generality of this unusual transformation and at confirming the identity of the observed decomposition product, before attempting to rationalize the decomposition mechanism.

\section{(c) Addition of pyridine to $\left[\mathrm{PtBr}_{3}\left(\mathrm{C}_{2} \mathrm{H}_{4}\right)\right]^{-}$}

Searching for other non deprotonatable amines, we considered the use of pyridine, with the additional advantage over triethylamine of a greater nucleophilic power. Addition of four equivalents of pyridine to the $\mathrm{CD}_{2} \mathrm{Cl}_{2}$ solution of $\mathbf{1}$ (as the $n \mathrm{Bu}_{4} \mathrm{P}^{+}$salt) did not produce any immediate change the room temperature ${ }^{1} \mathrm{H}$ NMR spectrum. A low temperature NMR analysis was not carried out in this case, but related low temperature NMR studies have previously provided evidence of the reversible addition of pyridine to trans-[ $\left[\mathrm{PtCl}_{2}(\mathrm{py})\left(\mathrm{C}_{2} \mathrm{H}_{4}\right)\right]{ }^{48,49}$ Upon standing overnight under argon and protected from light, the NMR tube gave rise to the growth of yellow crystals and no observable formation of metallic platinum. The crystals were analyzed by X-ray diffraction, revealing the formation of complex cis-[ $\left.\operatorname{PtBr}_{2}(\mathrm{py})_{2}\right]$, see Figure 3. The greater coordinating power of pyridine is clearly responsible for the ligand exchange process, overruling the nucleophilic addition to coordinated ethylene and leading to loss of ethylene from the coordination sphere. The key structural parameters are given in the legend of Figure 3. A similar structure has previously been described for the aniline adduct, cis-[ $\left.\mathrm{PtBr}_{2}\left(\mathrm{PhNH}_{2}\right)_{2}\right]$, obtained by double ligand exchange from $\left[n \mathrm{Bu}_{4} \mathrm{P}\right]_{2}\left[\mathrm{PtBr}_{4}\right]$ and aniline. ${ }^{8}$ It is worthy of note that the study of pyridine addition to trans-[ $\left.\mathrm{PtCl}_{2}(\mathrm{py})\left(\mathrm{C}_{2} \mathrm{H}_{4}\right)\right]$ have only resulted in reversible addition to the coordinated ethylene and pyridine exchange, with no reported exchange of the olefin ligand. ${ }^{49}$ 


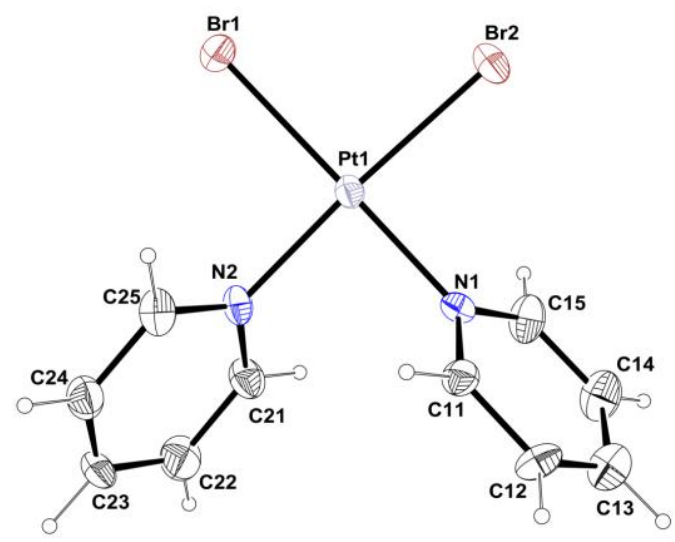

Figure 3. ORTEP view of complex cis-[ $\left.\mathrm{PtBr}_{2}(\mathrm{py})_{2}\right]$. Selected parameters (distances in $\AA$, angles in degrees): Pt1-Br1, 2.4253(8); Pt1-Br2, 2.4082(8); Pt1-N1, 2.023(6); Pt1-N2, 2.007(6); Br1Pt1-Br2, 91.66(3); Br1-Pt1-N1, 178.61(17); Br1-Pt1-N2, 91.82(18); Br2-Pt1-N1, 88.89(16); Br2Pt1-N2, 176.53(18); N1-Pt1-N2, 87.6(2).

\section{(d) Addition of quinuclidine to trans-[PtBr2 $\left.2\left(\mathrm{NHEt}_{2}\right)\left(\mathrm{C}_{2} \mathrm{H}_{4}\right)\right]$}

Quinuclidine is electronically similar to triethylamine but has a much greater nucleophilic power given its much smaller steric demand. The addition of 2 equivalents of quinuclidine to compound 7 at $-80^{\circ} \mathrm{C}$ in $\mathrm{CD}_{2} \mathrm{Cl}_{2}$ and immediate ${ }^{1} \mathrm{H}$ NMR monitoring shows evidence for quinuclidine nucleophilic addition to the coordinated ethylene with formation of a zwitterionic product (mutually coupled triplets for the $\mathrm{Pt}-\mathrm{CH}_{2} \mathrm{CH}_{2}-\mathrm{N}$ moiety at $\delta 3.16$ and $1.78, \mathrm{~J}=8.8 \mathrm{~Hz}$ ), but also of incipient ligand exchange with the release of free $\mathrm{Et}_{2} \mathrm{NH}$, see SI (Figure S2). A yellow precipitate appeared rapidly at low temperature and increased by subsequent warming to room temperature, while there was no evidence for the formation of metallic platinum. It is possible that this solid, which was not isolated and further investigated, corresponds to a bis(quinuclidine) complex similar to that obtained with pyridine and presented in the above 
section. Since it seems that strongly nucleophilic amines divert the reactivity toward exchange of the ethylene ligand and prevent the reductive decomposition process, we have abandoned this strategy.

\section{(e) Addition of sodium methoxide to trans-[ $\left.\mathrm{PtBr}_{2}\left(\mathrm{NHEt}_{2}\right)\left(\mathrm{C}_{2} \mathrm{H}_{4}\right)\right]$}

Given the recently reported evidence that the product of $\mathrm{MeO}^{-}$addition to certain $\mathrm{Pt}^{\mathrm{II}}$-ethylene complexes results in the elimination of methyl vinyl ether and reduction to $\mathrm{Pt}^{0},{ }^{41}$ we wished to test the reactivity of compound 7 with this nucleophile. $\mathrm{NaOMe}$ is insoluble in dichloromethane, thus we could not observe the formation of the methoxyethyl product at low temperatures. Nevertheless, treatment of the $\mathrm{CD}_{2} \mathrm{Cl}_{2}$ solution of 7 at room temperature with 5 equivalents of $\mathrm{NaOMe}$ led to complete degradation of the starting material over $48 \mathrm{~h}$ and to the generation of methanol $\left(\mathrm{CH}_{3}\right.$ resonance at $\delta$ 3.45). The decomposition was accompanied by the massive precipitation of black $\mathrm{Pt}^{0}$. The final ${ }^{1} \mathrm{H}$ NMR spectrum of the solution is available in the Supporting Information (Figure S3). In this spectrum, the most striking feature is the presence of two mutually coupled resonance (confirmed by a ${ }^{1} \mathrm{H}$ COSY NMR experiment) at $\delta 7.71$ (triplet) and 3.38 (doublet) with $\mathrm{J}_{\mathrm{HH}}=9 \mathrm{~Hz}$. These resonances are identical in chemical shift and coupling constant to those obtained for the product of the decomposition of compound 7 in the presence of $\mathrm{Et}_{3} \mathrm{~N}$.

This evidence suggests that the addition of either $\mathrm{NEt}_{3}$ or $\mathrm{MeO}^{-}$to compound 7 leads to the same product, which therefore contains neither $\mathrm{NEt}_{3}$ not $\mathrm{MeO}^{-}$. The two mutually coupled triplet and doublet resonances are reminiscent of the $\mathrm{Pt}-\mathrm{CH}_{2} \mathrm{CHNRR}$ ' derivatives reported by $\mathrm{BN} .{ }^{37} \mathrm{We}$ therefore speculated that the common product is trans-[ $\left.\mathrm{PtBr}_{2}\left(\mathrm{Et}_{2} \mathrm{NH}\right)\left(\mathrm{CH}_{2} \mathrm{CHNEt}_{2}\right)\right]$, 11, containing two diethylamine functions, one bonded as a ligand to platinum and the second one covalently bonded as an iminium function to a carbon atom. The basic reagents $\left(\mathrm{NEt}_{3}\right.$ or $\left.\mathrm{MeO}^{-}\right)$ 
start the reaction by the experimentally observed (for $\mathrm{Et}_{3} \mathrm{~N}$ ) nucleophilic addition to the olefin carbon, but ultimately participate to the reaction stoichiometry just as Brønsted bases by capturing the two protons. The resulting proposed stoichiometry is a revised version of that advanced by $\mathrm{BN},{ }^{37}$ as shown in equation 3 .

$$
2 \text { trans }-\left[\mathrm{PtBr}_{2}\left(\mathrm{NHEt}_{2}\right)\left(\mathrm{C}_{2} \mathrm{H}_{4}\right)\right]+2 \mathrm{Y} \rightarrow \text { trans }-\left[\mathrm{PtBr}_{2}\left(\mathrm{NHEt}_{2}\right)\left(\mathrm{CH}_{2} \mathrm{CHNEt}_{2}\right)\right]+
$$

7

$$
\begin{aligned}
\mathrm{Pt}^{0}+\mathrm{C}_{2} \mathrm{H}_{4}+2 \mathrm{YH}^{+}+2 \mathrm{Br}^{-} \\
\left(\mathrm{Y}=\mathrm{Et}_{3} \mathrm{~N}, \mathrm{MeO}^{-}, \mathrm{NHEt}_{2}\right)
\end{aligned}
$$

\section{(f) Preparation and characterization of trans-[ $\left.\mathrm{PtBr}_{2}\left(\mathrm{NHEt}_{2}\right)\left(\mathrm{CH}_{2} \mathrm{CHNEt}_{2}\right)\right]$}

In order to confirm the validity of the above assumptions, namely the stoichiometry of equation 3 and the identity of the $\mathrm{Pt}^{\mathrm{II}}$ product $\mathbf{1 1}$ as containing the $\mathrm{CH}_{2} \mathrm{CHNEt}_{2}$ ligand, we have repeated the reaction between compound 7 and only one equivalent of $\mathrm{Et}_{3} \mathrm{~N}$ per $\mathrm{Pt}$ on a larger scale. After one week at room temperature, the mixture contained a black $\mathrm{Pt}^{0}$ precipitate while the starting material had completely disappeared. Subsequent purification of the soluble product by chromatography on silica gel using dichloromethane as eluent produced a spectroscopically pure material, where all resonances (see Figure S4) could be clearly identified and assigned, also with the help of a COSY spectrum (Figure S5), to the corresponding protons of the proposed formulation of 11 as trans-[ $\left.\mathrm{PtBr}_{2}\left(\mathrm{NHEt}_{2}\right)\left(\mathrm{CH}_{2} \mathrm{CHNEt}_{2}\right)\right]$. Notably, we observe again the mutually coupled $\left(\mathrm{J}_{\mathrm{HH}}=9.2 \mathrm{~Hz}\right)$ triplet and doublet resonances at $\delta 7.71$ and 3.46 corresponding to 1 and 2 protons, the methylene and methyl resonances of the Pt-coordinated $\mathrm{Et}_{2} \mathrm{NH}$ ligand (the diastereotopic methylene protons are diagnostically present as two multiplets whereas the $\mathrm{Me}$ protons are equivalent) and those of the two inequivalent Et groups of the enamine $\mathrm{NEt}_{2}$ moiety, 
with the correct relative intensities. All these resonances are very close to those previously reported for the analogous dichloride derivative. ${ }^{37}$

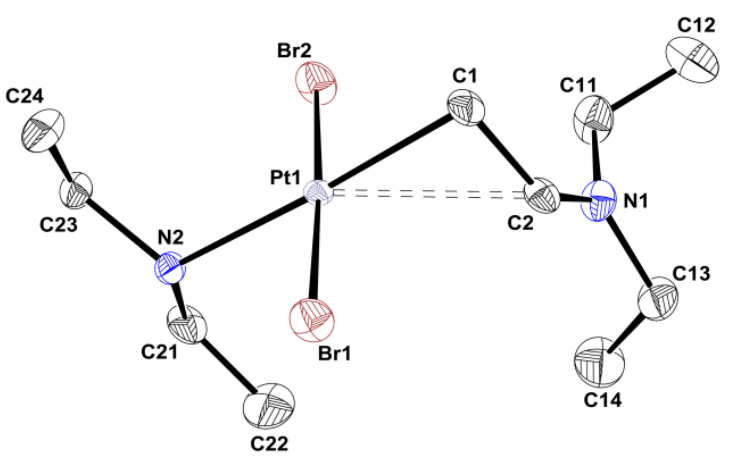

Figure 4. ORTEP view of complex trans-[ $\left.\mathrm{PtBr}_{2}\left(\mathrm{Et}_{2} \mathrm{NH}\right)\left(\mathrm{CH}_{2} \mathrm{CHNEt}_{2}\right)\right]$, 11. Selected parameters (distances in $\AA$, angles in degrees): Pt1-Br1, 2.4287(6); Pt1-Br2, 2.4173(6); Pt1-N2, 2.133(4); Pt1-C1, 2.097(5); C1-C2, 1.414(8); C2-N1, 1.313(7); Br1-Pt1-Br2, 177.434(18); Br1-Pt1-N2, 88.34(12); Br1-Pt1-C1, 90.63(17); Br2-Pt1-N2, 89.94(12); Br2-Pt1-C1, 90.96(17); N2-Pt1-C1, 176.16(18); Pt1-C1-C2, 96.3(4).

The formulation of the product $\mathbf{1 1}$ was further confirmed by an X-ray single crystal diffraction study. A view of the molecule is shown in Figure 4. The coordination geometry is as expected for a $d^{8} \mathrm{Pt}^{\mathrm{II}}$ complex with four ligands occupying approximately the four corners of a square plane. The two $\mathrm{Br}$ ligands are located on opposite corners, the other two hosting the $\mathrm{Et}_{2} \mathrm{NH}$ and $\mathrm{CH}_{2} \mathrm{CHNEt}_{2}$ ligands. Unfortunately, the crystal quality did not allow the $\mathrm{H}$ atoms of the Ptbonded $\mathrm{CH}_{2}$ group to be located, but the single $\mathrm{H}$ atom of the $\mathrm{C}$ atom bonded to the $-\mathrm{N}^{(+)} \mathrm{Et}_{2}$ moiety was indeed observed at the expected position in the difference Fourier map. The Pt-Br and Pt-N distances are similar to those reported for the structure of the precursor complex 7 (2.4191(5) and 2.4201(6) $\AA$ for the former, 2.089(4) $\AA$ for the latter). The most interesting 
feature of this structure is the configuration adopted by the $-\mathrm{CH}_{2} \mathrm{CHNEt}_{2}$ ligand. As mentioned in the introduction (Scheme 2) this ligand may adopt in principle an enamine configuration $\left(\mathrm{CH}_{2}=\mathrm{CH}-\mathrm{NEt}_{2}\right)$ or an iminiumalkyl configuration $\left({ }^{(-)} \mathrm{CH}_{2}-\mathrm{CH}=\mathrm{N}^{(+)} \mathrm{Et}_{2}\right)$. The Pt atom is too far from atom $\mathrm{C} 2(2.655 \AA)$ for the expected $\pi$ coordination of the enamine limiting structure whereas the Pt1-C1-C2 angle is too narrow $\left(96.3^{\circ}\right)$ for the expected $\sigma$ coordination of the iminiumalkyl ligand.

Table 2. Comparison of relevant structural parameters for enamine complexes of square planar $\mathrm{Pt}^{\mathrm{II}}$.

\begin{tabular}{|l|l|l|l|l|l|}
\hline Compound & $\mathrm{Pt}-\mathrm{C} 1$ & $\mathrm{Pt}-\mathrm{C} 2$ & $\mathrm{C} 1-\mathrm{C} 2$ & $\mathrm{C} 2-\mathrm{N}$ & Pt-C1-C2 \\
\hline cis $-\left[\mathrm{PtCl}_{2}\left(\mathrm{PPh}_{3}\right)\left(i \mathrm{PrCH}=\mathrm{CHNH}\left(o-\mathrm{C}_{6} \mathrm{H}_{4} \mathrm{Cl}\right)\right)\right]^{\mathrm{a}}$ & 2.21 & 2.31 & 1.38 & 1.37 & 76.2 \\
\hline trans $-\left[\mathrm{PtBr}_{2}\left(\mathrm{Et}_{2} \mathrm{NH}\right)\left(\mathrm{CH}_{2} \mathrm{CHNEt}_{2}\right)\right], \mathbf{1 1}$ & 2.097 & 2.655 & 1.414 & 1.313 & 96.3 \\
\hline trans $-\left[\mathrm{PtCl}_{2}\left(2,4,6-\mathrm{NC}_{5} \mathrm{H}_{2} \mathrm{Me}_{3}\right)\left(\mathrm{CH}_{2} \mathrm{CH}=\mathrm{N}(\mathrm{OH}) t \mathrm{Bu}\right)\right]^{\mathrm{b}}$ & 2.09 & 2.70 & 1.53 & 1.22 & 95 \\
\hline
\end{tabular}

${ }^{\mathrm{a}}$ From ref. ${ }^{50} .{ }^{\mathrm{b}}$ From ref. ${ }^{51}$.

The observed configuration may be compared with those reported for cis$\left[\mathrm{PtCl}_{2}\left(\mathrm{PPh}_{3}\right)\left(i \mathrm{PrCH}=\mathrm{CHNH}\left(o-\mathrm{C}_{6} \mathrm{H}_{4} \mathrm{Cl}\right)\right)\right],{ }^{50}$ which is best described as having an enamine ligand, and for trans- $\left[\mathrm{PtCl}_{2}\left(2,4,6-\mathrm{NC}_{5} \mathrm{H}_{2} \mathrm{Me}_{3}\right)\left(\mathrm{CH}_{2} \mathrm{CH}=\mathrm{N}(\mathrm{OH}) t \mathrm{Bu}\right)\right],{ }^{51}$ to which the iminiumalkyl configuration was assigned, see Table 2. Whereas the pattern of Pt-C distances and Pt-C1-C2 angle for $\mathbf{1 1}$ appears closer to that of the iminiumalkyl complex, the trends of the C1-C2 and C2$\mathrm{N}$ distances in the three complexes clearly point to compound $\mathbf{1 1}$ having a configuration 
intermediate between the two extremes. The interaction between atoms Pt1 and C2 in $\mathbf{1 1}$ must be very weak to account for the equivalence of the methylene protons in the ${ }^{1} \mathrm{H}$ NMR spectrum.

\section{(g) Discussion of the zwitterion decomposition mechanism.}

The results presented in the previous sections demonstrate that compound 7 leads to the deposition of $\mathrm{Pt}^{0}$ and formation of the enamine complex $\mathbf{1 1}$ when treated with a strong base. This occurs not only when the base is $\mathrm{Et}_{2} \mathrm{NH}$ (i.e. identical to the ligand that is already present in 7), as also shown by $\mathrm{BN}$ for the analogous dichloride system, ${ }^{37}$ but also when using $\mathrm{Et}_{3} \mathrm{~N}$ or $\mathrm{MeO}^{-}$, according to equation 3. Obviously, the mechanism proposed by $\mathrm{BN}$ cannot explain the formation of compound 11, at least when using non deprotonatable nucleophilic reagents.

On the basis of first principles and previous literature evidence, we propose the following alternative mechanism (Scheme 5). Equilibrium addition of the Y nucleophile to the coordinated ethylene in 7 affords the zwitterion $\mathbf{I}$, as experimentally observed for $\mathrm{Y}=\mathrm{NHEt}_{2}$ in a previous contribution ${ }^{15}$ and $\mathrm{NEt}_{3}$ in the present one. The reaction then proceeds from this intermediate by $\beta$-H elimination, to yield the hydride-olefin complex II. Olefin loss and deprotonation at this stage (as shown for the $\left[\mathrm{PtCl}(\mathrm{H})\left(2,9-\mathrm{Me}_{2} \text { phen) }\right] \text { intermediate in Scheme } 3\right)^{41}$ would lead to the immediate generation of $\mathrm{Pt}^{0}$ and $\mathrm{CH}_{2}=\mathrm{CHY}$ (vinylammonium if $\mathrm{Y}=\mathrm{NHEt}_{2}$ or $\mathrm{NEt}_{3}$, vinyl ether if $\mathrm{Y}=\mathrm{MeO}^{-}$), which are not observed for our system. Rather, we propose that the enhanced electrophilicity of the coordinated olefin, which is activated not only by coordination to platinum but also by the electron withdrawing power of $\mathrm{Y}$, triggers an intramolecular nucleophilic attack by the amine ligand which should preferentially occur on the Y-substituted carbon atom for electronic reasons. $\mathrm{Et}_{2} \mathrm{NH}$ does not have available lone pairs when coordinated, but the electron richness and the presence of trans-labilizing ligands in the complex may favor its departure from 
the coordination sphere and the $\mathrm{N}$ lone pair becomes then available for attacking the unsaturated ligand. It is in fact possible that the $\beta-\mathrm{H}$ elimination step occurs on a 14-electron $\left[\mathrm{Pt}^{(-)} \mathrm{Br}_{2}\left(\mathrm{CH}_{2} \mathrm{CH}_{2} \mathrm{Y}\right)\right]$ species after decoordination of the amine ligand, which then immediately attacks the newly formed $\mathrm{CH}_{2}=\mathrm{CHY}$ ligand. The course of this reaction, as opposed to that observed for the $\left[\mathrm{PtCl}\left(2,9-\mathrm{Me}_{2} \text { phen }\right)\left(\mathrm{C}_{2} \mathrm{H}_{4}\right)\right]^{+}$complex, ${ }^{41}$ may be related to the greater lability of $\mathrm{Et}_{2} \mathrm{NH}$ relative to the chelating 2,9- $\mathrm{Me}_{2}$ phen ligand.

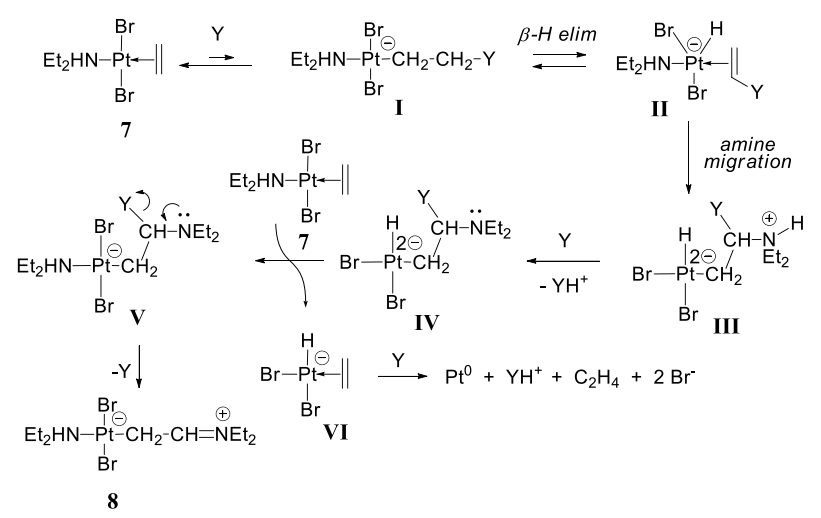

Scheme 5. Proposed mechanism for the decomposition of trans-[ $\left.\mathrm{PtBr}_{2}\left(\mathrm{Et}_{2} \mathrm{NH}\right)\left(\mathrm{C}_{2} \mathrm{H}_{4}\right)\right]^{-}$in the presence of Brønsted bases.

Complex III still features a hydride ligand. The latter is however bonded to a highly charged platinum atom (2- formal charge) and is thus presumably resistant to deprotonation. The $-\mathrm{N}^{(+)} \mathrm{HEt}_{2}$ ammonium group, on the other hand, is acidic and can be deprotonated by $\mathrm{Y}$, leading to $\mathbf{I V}$. The hydride ligand in $\mathbf{I V}$ is still under the influence of a very electron-rich $\mathrm{Pt}^{\mathrm{II}}$ center and therefore not deprotonatable. It should, on the contrary, be strongly hydridic. Therefore, we propose that a ligand exchange involving the hydride ligand in the dianion $\mathbf{I V}$ and the $\mathrm{Et}_{2} \mathrm{NH}$ ligand in neutral 7 takes place at this point, yielding the two monoanionic complexes $\mathbf{V}$ and VI. 
Complex V may then expel Y, leading to the observed product 11 (the expulsion of Y may also occur on intermediate IV, before the ligand exchange with 7) whereas complex VI, featuring the hydride ligand in a now less electron-rich environment, may be deprotonated leading to $\mathrm{Pt}^{0}$, free $\mathrm{C}_{2} \mathrm{H}_{4}$, and two $\mathrm{Br}^{-}$ions.

There are several key features leading to this transformation. The first one is that $\mathrm{Y}$ is a poorer ligand than $\mathrm{Et}_{2} \mathrm{NH}$ and thus cannot replace the latter and bind the metal. This is not the case, for instance, for pyridine and quinuclidine that are even capable of replacing the olefin and lead to cis-bis-amine adducts. Secondly, $\mathrm{Y}$ is also a less powerful nucleophile than $\mathrm{Et}_{2} \mathrm{NH}$ but is nevertheless capable of attacking the olefin as shown by the low-temperature NMR experiments (at least when $\mathrm{Y}=\mathrm{NEt}_{3}$ ). However, it preferentially leaves the carbyl ligand in intermediate $\mathbf{V}$ to yield the enamine complex 11 rather than protonation-assisted loss of $\mathrm{Et}_{2} \mathrm{NH}$ to generate a putative trans-[ $\left.\mathrm{PtBr}_{2}\left(\mathrm{Et}_{2} \mathrm{NH}\right)\left(\mathrm{CH}_{2} \mathrm{CHY}\right)\right]$ product. On the other hand, it is a strong Brønsted base and can thus serve well in this capacity to capture the protons that are generated along the transformation.

One still obscure point is the fate of the zwitterion $\mathbf{9}$, since no protons are available neither on the ammonium function not on the coordinated amine, but the formation of the predicted vinylammonium product could not be observed. It is possible that the expelled vinylammonium cation is subject to further transformations under these reaction conditions (excess tertiary amine) and proceeds to a final product that we have not yet been able to identify. However, even the zwitterion 9 ultimately decomposes to generate metallic platinum, consistent with the formation of a platinum hydride intermediate by $\beta-\mathrm{H}$ elimination. 


\section{Conclusion.}

In pursuit of understanding the mechanism of decomposition of the $\mathrm{PtBr}_{2} / \mathrm{Br}^{-}$catalyst for ethylene hydroamination by aniline, we have studied the details of the addition of non deprotonatable bases $\left(\mathrm{Et}_{3} \mathrm{~N}\right.$, pyridine, quinuclidine, $\mathrm{MeONa}$ ) to coordinated ethylene in the model compound trans-[ $\mathrm{PtBr}_{2}\left(\mathrm{NHEt}_{2}\left(\mathrm{C}_{2} \mathrm{H}_{4}\right)\right](7)$, as well as in the catalytic resting state $\left[\mathrm{PtBr}_{3}\left(\mathrm{C}_{2} \mathrm{H}_{4}\right)\right]^{-}(\mathbf{1})$. Bases with a considerable nucleophilic power (pyridine, quinuclidine) are able to replace the ethylene ligand. On the other hand, $\mathrm{Et}_{3} \mathrm{~N}$ and $\mathrm{MeONa}$ lead to the deposition of metallic platinum demonstrating that, contrary to a previous suggestion, the reduction of the $\mathrm{Pt}^{\mathrm{II}}\left(\mathrm{C}_{2} \mathrm{H}_{4}\right) /$ amine system does not require deprotonation of the zwitterion intermediate. The isolation and characterization of complex trans- $\left[\mathrm{PtBr}_{2}\left(\mathrm{NHEt}_{2}\right)\left(\mathrm{CH}_{2} \mathrm{CHNEt}_{2}\right)\right]$, 11, when the reaction is conducted from 7 allows a new mechanistic interpretation of the metal reduction process as involving a Wacker-type $\beta-\mathrm{H}$ elimination from the zwitterionic intermediate as the key step.

On the basis of this new understanding, it is clear that Brunet's $\mathrm{PtBr}_{3} / \mathrm{Br}^{-}$catalytic system cannot be made active for the hydroamination of olefin by basic amines. Other platinum complexes may prove more active or less sensitive to reductive decomposition if appropriate modifications to the coordination sphere around the catalytic center can be envisaged to protect the zwitterionic intermediate against the $\beta-\mathrm{H}$ elimination process and/or the resulting hydride complex against deprotonation. 


\section{AUTHOR INFORMATION}

\section{Corresponding Author}

*Rinaldo Poli. LCC (Laboratoire de Chimie de Coordination), 205 route de Narbonne, BP 44099, F-31077 Toulouse Cedex 4, France. Tel +33-561333173. Fax +33-561553003. Email: rinaldo.poli@1cc-toulouse.fr.

\section{Author Contributions}

The manuscript was written through contributions of all authors. All authors have given approval to the final version of the manuscript.

\section{ACKNOWLEDGMENT}

We are grateful to the Centre National de la Recherche Scientifique (CNRS), the Institut Universitaire de France (IUF), and the Agence Nationale de la Recherche (ANR, Grant «HYDROAM » No. NT09_442499) for financial support.

\section{ABBREVIATIONS}

BN, Balacco and Natile (ref. 37); DMSO, DiMethylSulfOxide; DBU, 1,8-DiazaBicyclo[5.4.0]Undec-7-ene; DFT, Density Functional Theory; phen, phenantroline.

REFERENCES (Word Style "TF_References_Section”).

(1) Brunet, J.-J.; Neibecker, D. In Catalytic Heterofunctionalization from Hydroamination to Hydrozirconation; Togni, A., Grützmacher, H., Eds.; VCH: Weinheim, 2001, p 91-141. 
(2) Brunet, J.-J.; Chu, N.-C.; Rodriguez-Zubiri, M. Eur. J. Inorg. Chem. 2007, 4711-4722.

(3) Müller, T. E.; Hultzsch, K. C.; Yus, M.; Foubelo, F.; Tada, M. Chem. Rev. 2008, 108, 3795-3892.

(4) Brunet, J. J.; Cadena, M.; Chu, N. C.; Diallo, O.; Jacob, K.; Mothes, E. Organometallics 2004, 23, 1264-1268.

(5) Rodriguez-Zubiri, M.; Anguille, S.; Brunet, J.-J. J. Mol. Catal. A 2007, 271, 145-150.

(6) Brunet, J. J.; Chu, N. C.; Diallo, O. Organometallics 2005, 24, 3104-3110.

(7) Dub, P. A.; Rodriguez-Zubiri, M.; Baudequin, C.; Poli, R. Green Chem. 2010, 13921396.

(8) Dub, P. A.; Rodriguez-Zubiri, M.; Daran, J.-C.; Brunet, J.-J.; Poli, R. Organometallics 2009, 28, 4764-4777.

(9) Dub, P. A.; Poli, R. J. Mol. Catal. A 2010, 324, 89-96.

(10) Dub, P. A.; Béthegnies, A.; Poli, R. Organometallics 2012, 31, 294-305.

(11) Dub, P. A.; Poli, R. J. Am. Chem. Soc. 2010, 132, 13799-13812.

(12) Dub, P. A.; Béthegnies, A.; Poli, R. Eur. J. Inorg. Chem. 2011, 5167-5172.

(13) Michon, C.; Medina, F.; Capet, F.; Roussel, P.; Agbossou-Niedercorn, F. Adv. Synth. Catal. 2010, 352, 3293-3305.

(14) Béthegnies, $\quad$ A.; Poli, $\quad$ R. J. Jrganom. Chem. http://dx.doi.org/10.1016/j.jorganchem.2012.12.017. 
(15) Dub, P. A.; Daran, J.-C.; Levina, V. A.; Belkova, N. V.; Shubina, E. S.; Poli, R. J. Organomet. Chem 2011, 696, 1174-1183.

(16) Maresca, L.; Natile, G.; Manottilanfredi, A. M.; Tiripicchio, A. J. Am. Chem. Soc. 1982, $104,7661-7662$

(17) Maresca, L.; Natile, G. Chem. Commun. 1983, 40-41.

(18) Fanizzi, F. P.; Maresca, L.; Natile, G.; Pacifico, C. Gazz. Chim. Ital. 1994, 124, 137-142.

(19) Maresca, L.; Natile, G. Comm. Inorg. Chem. 1994, 16, 95-112.

(20) Hahn, C.; Morvillo, P.; Herdtweck, E.; Vitagliano, A. Organometallics 2002, 21, 18071818.

(21) Vicente, J.; Chicote, M. T.; Macbeath, C.; Jones, P. G. Organometallics 2003, 22, $1843-$ 1848.

(22) Benedetti, M.; Fanizzi, F. P.; Maresca, L.; Natile, G. Chem. Commun. 2006, 1118-1120.

(23) Barone, C. R.; Benedetti, M.; Vecchio, V. M.; Fanizzi, F. P.; Maresca, L.; Natile, G. Dalton Trans. 2008, 5313-5322.

(24) Panunzi, A.; De Renzi, A.; Palumbo, R.; Paiaro, G. J. Amer. Chem. Soc. 1969, 91, 38793883.

(25) Panunzi, A.; De Renzi, A.; Paiaro, G. J. Am. Chem. Soc. 1970, 92, 3488-3489.

(26) Benedetti, E.; De Renzi, A.; Paiaro, G.; Panunzi, A.; Pedone, C. Gazz. Chim. Ital. 1972, $102,744-754$. 
(27) Hollings, D.; Green, M.; Claridge, D. V. J. Organometal. Chem. 1973, 54, 399-402.

(28) Al-Najjar, I. M.; Green, M. J. Chem. Soc., Dalton Trans. 1979, 1651-1656.

(29) Green, M.; Sarhan, J. K. K.; Alnajjar, I. M. J. Chem. Soc., Dalton Trans. 1981, 15651571.

(30) De Renzi, A.; Di Blasio, B.; Morelli, G.; Vitagliano, A. Inorg. Chim. Acta 1982, 63, 233241.

(31) Annibale, G.; Maresca, L.; Natile, G.; Tiripicchio, A.; Tiripicchiocamellini, M. J. Chem. Soc., Dalton Trans. 1982, 1587-1591.

(32) Maresca, L.; Natile, G. J. Chem. Soc., Dalton Trans. 1982, 1903-1906.

(33) Sarhan, J. K. K.; Green, M.; Al-Najjar, I. M. J. Chem. Soc., Dalton Trans. 1984, 771-777.

(34) Green, M.; Sarhan, J. K. K.; Al-Najjar, I. M. Organometallics 1984, 3, 520-524.

(35) Lorusso, G.; Barone, C. R.; Di Masi, N. G.; Pacifico, C.; Maresca, L.; Natile, G. Eur. J. Inorg. Chem. 2007, 2144-2150.

(36) Mcbee, J. L.; Tilley, T. D. Organometallics 2010, 29, 184-192.

(37) Balacco, G.; Natile, G. J. Chem. Soc., Dalton Trans. 1990, 3021-3024.

(38) Vecchio, V. M.; Benedetti, M.; Migoni, D.; De Pascali, S. A.; Ciccarese, A.; Marsigliante, S.; Capitelli, F.; Fanizzi, F. P. Dalton Trans. 2007, 5720-5725.

(39) Barone, C. R.; Cini, R.; Clot, E.; Eisenstein, O.; Maresca, L.; Natile, G.; Tamasi, G. J. Organomet. Chem. 2008, 693, 2819-2827. 
(40) Benedetti, M.; Antonucci, D.; De Pascali, S. A.; Girelli, C. R.; Fanizzi, F. P. J. Organomet. Chem. 2012, 714, 60-66.

(41) Benedetti, M.; Antonucci, D.; De Pascali, S. A.; Ciccarella, G.; Fanizzi, F. P. J. Organomet. Chem. 2012, 714, 104-108.

(42) Armarego, W. L. F.; Perrin, D. D. Purification of Laboratory Chemicals; Butterworth Heinemann, 4th ed., 1996.

(43) Altomare, A.; Burla, M.; Camalli, M.; Cascarano, G.; Giacovazzo, C.; Guagliardi, A.; Moliterni, A.; Polidori, G.; Spagna, R. J. Appl. Cryst. 1999, 32, 115-119.

(44) Sheldrick, G. M. Acta Cryst. A 2008, 64, 112-122.

(45) Burnett, M. N.; Johnson, C. K. ORTEPIII, Report ORNL-6895. ; Oak Ridge National Laboratory: Oak Ridge, Tennessee, U.S. , 1996.

(46) Farrugia, L. J. J. Appl. Cryst. 1997, 30, 565.

(47) Ueyama, M.; Tori, K. Organic Magnetic Resonance 1972, 4, 913-918.

(48) Kaplan, P. D.; Schmidt, P.; Orchin, M. J. Amer. Chem. Soc. 1968, 90, 4175-4176.

(49) Natile, G.; Maresca, L.; Cattalini, L. J. Chem. Soc., Dalton Trans. 1977, 651-655.

(50) De Renzi, A.; Ganis, P.; Panunzi, A.; Vitagliano, A.; Valle, G. J. Am. Chem. Soc. 1980, $102,1722-1723$.

(51) Mansuy, D.; Dreme, M.; Chottard, J. C.; Girault, J. P.; Guilhem, J. J. Am. Chem. Soc. 1980, 102, 844-845. 
